\title{
A conceptual framework for latecomer linkage capabilities
}

\author{
Reinauer, Tobias; Hansen, Ulrich Elmer
}

Published in:

Industrial and Corporate Change

Link to article, DOI:

10.1093/icc/dtab014

Publication date:

2021

Document Version

Publisher's PDF, also known as Version of record

Link back to DTU Orbit

Citation (APA):

Reinauer, T., \& Hansen, U. E. (2021). A conceptual framework for latecomer linkage capabilities. Industrial and Corporate Change, 30(6), 1539-1556. https://doi.org/10.1093/icc/dtab014

\section{General rights}

Copyright and moral rights for the publications made accessible in the public portal are retained by the authors and/or other copyright owners and it is a condition of accessing publications that users recognise and abide by the legal requirements associated with these rights.

- Users may download and print one copy of any publication from the public portal for the purpose of private study or research.

- You may not further distribute the material or use it for any profit-making activity or commercial gain

- You may freely distribute the URL identifying the publication in the public portal

If you believe that this document breaches copyright please contact us providing details, and we will remove access to the work immediately and investigate your claim 


\title{
A conceptual framework for latecomer linkage capabilities
}

\section{Tobias Reinauer $^{1{ }^{*}}$ and Ulrich Elmer Hansen ${ }^{2}$}

'UNEP DTU Partnership, Department of Technology, Management, and Economics, Technical University of Denmark, Marmorvej 51, 2100 Copenhagen, Denmark. e-mail: tobre@dtu.dk and ${ }^{2}$ UNEP DTU Partnership, Department of Technology, Management, and Economics, Technical University of Denmark, Marmorvej 51, 2100 Copenhagen, Denmark. e-mail: uleh@dtu.dk

*Main author for correspondence.

\begin{abstract}
In this article, we put forward a framework for conceptualizing processes of linkage capability-building in firms based in developing countries, so-called latecomer firms. To do this, we combine the literature on latecomer capabilities with insights from the literature on industrial marketing and supplychain management. Our framework distinguishes between different levels of development across three capability categories: envisioning opportunities for useful market and knowledge-based linkages, engaging with external partners in ways that create suitable organizational arrangements, and exploiting relationships for technological learning.
\end{abstract}

JEL classification: $031,032,033$

\section{Introduction}

There is a rich literature investigating how firms in developing countries, often referred to as latecomer firms, increase their economic performance and competitiveness by building their technological capabilities (Dahlman et al., 1987; Lall, 1992; Kim, 1997; Romijn, 1997; Bell and Figueiredo, 2012; Dutrénit et al., 2013). This literature has produced numerous theoretical frameworks for understanding the capability-building process and has provided empirical insights into the experiences of various firms, industries, and economies.

Particularly relevant in this regard has been the conceptualization of different capability functions within latecomer firms. In a seminal paper, Lall (1992) introduced a framework for analyzing sets of such functions, including capabilities for pre-investment activities, project execution, process engineering, product design, industrial engineering, and linkage to external partners. For each of these functions, Lall defines multiple stages of complexity through which the latecomer firm progresses as it moves up the capability trajectory. He argues that the firm needs to develop at least a minimum level of competence in each function in order to be able to operate successfully in competitive markets. The idea of different capability functions has subsequently been adopted by a large number of studies in the literature on latecomer capability-building (e.g., Bell and Pavitt, 1995; Figueiredo, 2003; Ariffin and Figueiredo, 2004; Kiamehr, 2017). These provide frameworks that provide more granular categorizations of various capability functions and levels of advancement, often in relation to particular industries. 
While this literature contains detailed descriptions of different kinds of production- and investment-related capability functions, the conceptual understanding of the category of linkage capabilities has remained largely unchanged since Lall's (1992) original work. Linkage capabilities are defined as those required to transfer knowledge and skills to, and receive them from, different kinds of actors in the domestic economy and abroad (ibid.: 168). This concerns linkages with a variety of market and nonmarket actors, including suppliers of components and raw materials, subcontractors, technology users, retailers, consultants, standard-setting bodies, quality-testing laboratories, and research institutes.

The limited amount of attention that has been paid to this particular type of capability is somewhat surprising, as linkages with external partners, both local and international, have been identified as key to technological learning processes (Bell and Figueiredo, 2012). This is particularly relevant in the case of latecomer firms, which initially have underdeveloped internal resources and therefore rely strongly on external sources of knowledge to build their capabilities (Arnold and Thuriaux, 1997; Caniels and Romijn, 2004). In fact, linkage capabilities seem to be at the heart of common definitions of the latecomer firm, which emphasize that the latecomer is characterized by limited access to advanced markets and sources of technology, either because of its geographical location (Hobday, 1995) or due to its inability to make use of existing networks (Bell and Figueiredo, 2012: 25). Hence, developing an understanding of the factors that allow latecomer firms to make effective use of the available external sources of knowledge appears to be key to understanding how such firms can build up their stocks of capabilities for production- and investmentrelated activities.

This article contributes to the literature on latecomer capability-building by introducing a framework conceptualizing the formation of linkage capabilities in latecomer firms. In doing so, it aims to complement Lall's (1992) original framework by providing further nuances on this particular kind of capability. Specifically, we focus on three different kinds of capability that are required at different stages in the process of developing effective linkages: (i) envisioning opportunities for technological learning through interaction with external partners; (ii) engaging with partners to create suitable organizational mechanisms and procedures; and (iii) exploiting relationships for effective technological learning. Given our focus on latecomer firms, we also distinguish capabilities at different levels of competence and complexity within each of these categories.

The article is structured as follows. Section 2 reviews the literature on linkage capabilities, starting by reviewing relevant studies in the literature on latecomer capability-building. Next, it discusses a related strand of literature on industrial marketing and supply-chain management in order to distil relevant insights from it that can be integrated into our framework. Against this backdrop, Section 3 introduces our framework. Section 4 concludes the article by reflecting on the relevance of our framework for theories of technological capability-building processes at latecomer firms.

\section{Existing theory on linkage capabilities}

This section reviews two strands of literature that discuss the development of linkage capabilities. The first consists of investigations into technological capability-building in latecomer firms (reviewed by Bell and Figueiredo, 2012). As highlighted in the introduction to this article, there is rich body of literature seeking to explain how such firms develop their stocks of capability, but limited insights into how they develop linkages with other actors.

Second, a number of studies in the literature on industrial marketing and supply-chain management focus on the issue of linkage capabilities. This is a narrower line of investigation, one that provides useful insights into how to conceptualize processes of linkage-capability development. In contrast to studies of latecomer capabilities, this literature typically focuses on established firms that operate at or close to the global technological frontier. In contrast to latecomer firms, such frontier firms have already built up substantial stocks of capabilities, and their competitiveness primarily revolves around their ability to maintain and nurture these stocks, as opposed to building them up in the first place (Dutrénit, 2004; Bell and Figueiredo, 2012).

Both bodies of literature, on latecomer capabilities and on linkages in industrial marketing and supply-chain management, are grounded in the resource-based view of the firm (Penrose, 1959; Barney, 1991). However, they appear to have been developed in isolation from each other, as we have been unable to identify any cross-referencing between the publications we reviewed in preparation for this article. 


\subsection{Linkages in latecomer capability-building}

As highlighted previously, Lall (1992) introduced the concept of linkage capabilities in the literature on technological capability-building in latecomer firms. He devised a framework for analyzing a set of capability functions (pre-investment activities; project execution; process, product, industrial engineering, and linkages). For each of these functions, Lall provides an illustrative list of activities indicating which firms have accumulated capability stocks at different levels of complexity. In the case of linkage capabilities, this includes: (i) local procurement of goods and services and information exchange with suppliers at the lower end of the scale; (ii) technology transfers to local suppliers, coordinated design, and some science and technology links at the intermediate stage; and (iii) turnkey capabilities, cooperative research and development $(R \& D)$, and licensing of the firm's own technology to others at the upper end of the scale of complexity. Lall stresses that such linkage capabilities are critical to the firm's productivity. While useful in highlighting the importance of linkages for innovation activities in the context of latecomer firms, Lall's framework provides little insight into the specific kinds of capabilities that firms require as they go through the different stages of forming and making use of such linkages. As we shall demonstrate below, we believe it is useful to make more granular distinctions between the relevant types of capability involved.

Subsequent work on innovation capabilities in latecomer firms has paid little attention to the issue of linkage capabilities. Many authors in this literature have developed classifications of latecomer capabilities, usually focusing on specific industries (e.g., Dutrénit, 1998; Figueiredo, 2003; Gammeltoft, 2004; Ariffin, 2010). However, hardly any of these studies cover the firm's ability to create linkages with external partners as a separate capability category. The few studies that have done this adopt Lall's definition largely unchanged, including the seminal work of Bell and Pavitt (1995) and, more recently, Kiamehr (2017) and Whitfield et al. (2020). Others touch upon the subject indirectly when discussing aspects related to linkage capabilities, such as the characteristics of knowledge networks (Dantas and Bell, 2009), external technology-sourcing strategies (Iammarino et al., 2008; Hansen and Ockwell, 2014; Figueiredo, 2017; Hansen and Lema, 2019), or the role of informal linkages in technological learning (Chen, 2009). Yet others discuss linkage capabilities explicitly, but only do so briefly alongside a range of other findings, resulting in comparatively limited insights in this regard (Arnold and Thuriaux, 1997; Rush et al., 2007; Scott-Kemmis and Chitravas, 2007).

Mathews $(2002 \mathrm{a}, 2006,2017)$ provides what is perhaps the most comprehensive treatment of linkages for learning in latecomer firms since Lall (1992). He distinguishes between three elements in the process of learning from external partners: linkages (i.e., the establishment of contractual forms of partnership), leverage (shaping events in a partnership so as to facilitate knowledge transfer), and learning (the repeated application of linkages and leverage). While this framework has attracted much attention in the international business literature, we find that it has certain limitations. For instance, it focuses exclusively on interactions with foreign and technologically advanced partners, thus ignoring linkages to less technologically advanced actors within the economy in which the latecomer firm is located. The latter have been found to be critical for learning in latecomer firms, especially in the early stages of the capability-development trajectory (Plechero, 2012; Hansen and Ockwell, 2014; Hansen and Lema, 2019). Relatedly, Mathews does not explicitly distinguish between linkage capabilities at different levels of complexity, which means that advancing latecomer firms' abilities to learn from external linkages is not captured in detail. Furthermore, his framework does not account for the firm's ability to identify potentially fruitful opportunities for partnerships in the first place. We argue below that the ability to understand developments in markets and technology and to identify relevant capability needs and sources in order to make use of them are critical in this regard. As such, it is important to take them into account in the study of technological learning and capability-building in latecomer firms.

\subsection{Linkages in industrial marketing and supply-chain management}

The literature on industrial marketing and supply-chain management provides additional insights into the abilities of firms to develop linkages with external partners (see Forkmann et al. [2018] for a recent review). Building on the resource-based view of the firm (Penrose, 1959; Barney, 1991) and the dynamic capabilities approach (Teece, 1997; Eisenhardt and Martin, 2000), this literature focuses on how established firms, mostly based in industrialized countries, maintain and increase their competitiveness by nurturing and renewing their capabilities in constantly changing business environments. Studies in this field of research use a variety of terms to refer to linkage capabilities, including relational, networking, and alliance capabilities. While most works in this literature focus on market-based linkages to clients and suppliers, the insights we draw on here also apply to non-market linkages-for example, knowledge-based 
linkages to public research institutes—and, as such, conform to the definition of linkage capabilities we adopt in this article (see Section 1).

Some authors in the literature on industrial marketing and supply-chain management have developed frameworks with which to conceptualize the different components of a firm's ability to build relationships with its external partners. For example, Lambe et al. (2002) focus on what they call alliance competences in firm dyads (e.g., in manufacturer-supplier relationships, joint ventures, technology-licensing agreements, or R\&D collaborations), which they define as the interorganizational ability to find, develop, and manage alliances. They argue that this includes the abilities (i) to identify suitable partners through systematic and proactive scanning of the business environment, and (ii) to manage partnerships by articulating roles and responsibilities and dynamically reviewing the terms of the alliance over time. Mitrega et al. (2012) focus on relationships between a focal firm and a portfolio of suppliers in order to develop a similar framework. They distinguish between a firm's ability to initiate and to develop partnerships and, as an additional dimension, explicitly highlight its ability to terminate partnerships. Lorenzoni and Lipparini (1999) also focus on interactions between a focal firm and a network of suppliers. As opposed to the two frameworks mentioned previously, their conceptualization focuses less on the initiation and establishment of relationships and more on the ability of the lead firm to coordinate and combine knowledge and resources from a variety of partners.

These studies provide insights that can be usefully integrated into a framework for studying linkage capabilities in latecomer firms. They highlight different aspects of the linkage development process for which focal firms need to build capabilities. More specifically, they emphasize capabilities that are relevant for the identification of suitable external partners, the establishment and dynamic adjustment of the terms and conditions of the partnerships, and the absorption of knowledge derived from interactions with partners. Compared to the literature on latecomer capability reviewed in Section 2.1, this literature provides a more fine-grained view of the different stages involved in the development of linkages with external partners. However, the frameworks reviewed here (Section 2.2) do not provide many useful insights into how firms build linkage capabilities at different levels of complexity. As argued in Section 1 , latecomer firms operate under a number of specific conditions, including initially low capability stocks and limited access to advanced markets and sources of technology. This implies that the kinds of linkages they are able to develop at different stages of their development are likely to differ from those that are most appropriate for firms that operate close to the global technological frontier.

\section{A conceptual framework for latecomer linkage capabilities}

Our goal here is to introduce a nuanced model that illuminates the kinds of capabilities that latecomer firms need to develop in order to create effective linkages with external partners. For this purpose, we focus our discussion specifically on the nature of these capability stocks (Figure 1). In this article, we do not discuss the determinants of the development of such capabilities in any detail. That is, we do not investigate the learning processes that firms undergo to build their linkage capability stocks, for example, by accumulating experience through repeatedly making use of linkages. We also do not discuss in detail how the development of a latecomer firm's linkage capability stocks is associated with changes to certain outcomes variables. This includes outcomes in terms of both specific innovation

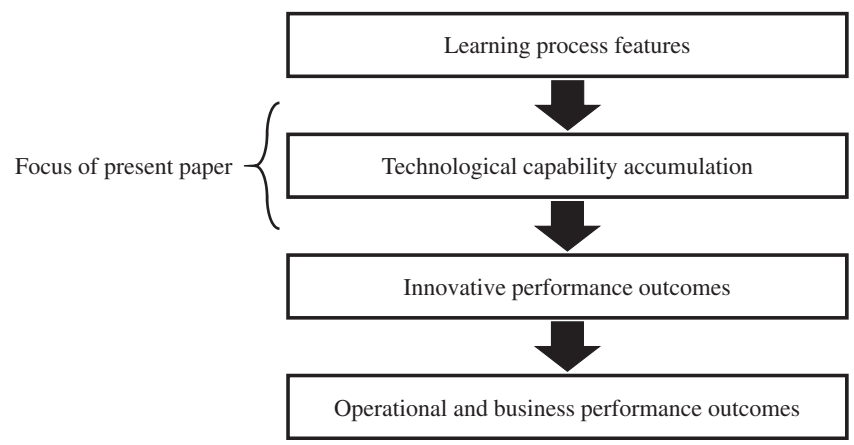

Figure 1. Focus of the present article. Adapted from Bell and Figueiredo (2012). 


\begin{tabular}{|c|c|c|c|c|c|c|c|}
\hline \multirow{3}{*}{$\begin{array}{c}\text { Lall } \\
(1992)\end{array}$} & & \multicolumn{2}{|c|}{ Investment } & \multicolumn{3}{|c|}{ Production } & \multirow{2}{*}{$\begin{array}{c}\begin{array}{c}\text { Supporting } \\
\text { activities }\end{array} \\
\text { Linkages }\end{array}$} \\
\hline & & $\begin{array}{c}\text { Pre- } \\
\text { investment }\end{array}$ & $\begin{array}{c}\text { Project } \\
\text { execution }\end{array}$ & $\begin{array}{c}\text { Process } \\
\text { engineering }\end{array}$ & $\begin{array}{c}\text { Product } \\
\text { engineering }\end{array}$ & $\begin{array}{c}\text { Industrial } \\
\text { engineering }\end{array}$ & \\
\hline & Advanced & $\ldots$ & $\ldots$ & $\ldots$ & $\ldots$ & $\ldots$ & $\ldots$ \\
\hline & Intermediate & $\ldots$ & $\ldots$ & $\ldots$ & $\ldots$ & $\ldots$ & $\cdots$ \\
\hline & Basic & $\ldots$ & $\cdots$ & $\ldots$ & $\ldots$ & $\ldots$ & $\ldots$ \\
\hline & & \multirow{4}{*}{\multicolumn{2}{|c|}{ Focus of present paper }} & & Envisioning & Engaging in & Exploiting \\
\hline & & & & Advanced & $\cdots$ & $\cdots$ & $\cdots$ \\
\hline & & & & Intermediate & $\ldots$ & $\ldots$ & $\ldots$ \\
\hline & & & & Basic & $\cdots$ & $\ldots$ & $\ldots$ \\
\hline
\end{tabular}

Figure 2. The focus of this article in relation to Lall's (1992) framework for latecomer-capability building.

activities resulting from capability accumulation, such as changes in particular products or processes, and the firm's more general operational and business performance.

We conceptualize technological capability-building as a firm-specific process that is cumulative and path dependent (Bell and Figueiredo, 2012). Furthermore, effective capability-building requires active management, as it typically takes place over long periods of time, involves substantial effort and financial outlay, and entails considerable uncertainty (ibid.).

We take our point of departure in Lall's (1992) work and focus in on the kinds of capabilities that are required to build effective linkages with external partners (Figure 2). Based on the insights from the literature on industrial marketing and supply-chain management (see Section 2.2), we consider three categories of capability. The first is the firm's ability to envision opportunities for potentially fruitful collaborations. Second, we consider the firm's ability to engage with partners in types of organizational arrangements that are likely to support its ability to benefit from the partnership by improving its existing stock of knowledge. Lastly, our framework considers the ability to exploit linkages with external partners, that is, the latecomer's ability to integrate externally accessed knowledge effectively into its firm-internal stock of knowledge.

Sections 3.1-3.3 discuss these three capability categories in more detail. Table 1 offers a summary. For each category, we first introduce key conceptual elements to consider and subsequently discuss different levels of advancement, from the basic through the intermediate to the advanced level. It should be noted that these levels refer to stages on a continuum of capability development. Our discussion of these stages is based on the so-called "revealed capabilities" approach, which involves inferring a firm's capabilities from information about its actions (Bell and Figueiredo, 2012: 50). This is a commonly used approach in the latecomer capability literature because it is difficult to measure directly the constituents of a firm's technological capabilities, such as knowledge bases, skills, and experience.

Furthermore, to offer some illustrative evidence for the mechanisms we propose in our framework, we draw on prior empirical analyses (and some conceptual studies) of latecomer capability-building. For this, we have conducted a comprehensive assessment of key studies in this field of research. Based on our review, we have compiled a large number of excerpts, which we selectively draw on in the discussion of our framework below. The complete list of quotes is included in an online appendix to the article.

\subsection{Envisioning linkages}

\subsubsection{Key concepts}

Based on the above literature review (Section 2), we argue that it is useful to conceptualize the ability of the firm to envision potentially fruitful linkages to external resources as a distinct category of capabilities. Identifying linkages is the first step in making use of them for the purposes of effective learning in the firm's production- and investmentrelated activities. We differentiate between three aspects of envisioning. 
Table 1. Conceptual framework to study latecomer-linkage capabilities

\begin{tabular}{|c|c|c|c|}
\hline Linkage capability level & Envision & Engage & Exploit \\
\hline Advanced & $\begin{array}{l}\text { Regular performance bench- } \\
\text { marking compared to leading } \\
\text { firms to identify opportunities } \\
\text { for improvement } \\
\text { Multiple and variegated linkages } \\
\text { to advanced partners in indus- } \\
\text { trialized economies to keep up } \\
\text { to date with the latest devel- } \\
\text { opments in technology and } \\
\text { markets } \\
\text { Strong alignment of competitive } \\
\text { and learning strategies }\end{array}$ & $\begin{array}{l}\text { Partnerships with a variety of } \\
\text { local and foreign firms, includ- } \\
\text { ing global leaders } \\
\text { Knowledge-intensive interorgani- } \\
\text { zational forms, including out- } \\
\text { ward foreign direct } \\
\text { investment in industrialized } \\
\text { economies } \\
\text { Symmetrical relationships aimed } \\
\text { at technology co-design, } \\
\text { including instances of reverse } \\
\text { technology transfer }\end{array}$ & $\begin{array}{l}\text { Highly interactive mechanisms } \\
\text { for knowledge acquisition as } \\
\text { part of outward-focused for- } \\
\text { eign direct investment } \\
\text { Effective knowledge integration } \\
\text { to combine and integrate } \\
\text { knowledge accessed from a } \\
\text { variety of external resources } \\
\text { with prior knowledge stock }\end{array}$ \\
\hline Intermediate & $\begin{array}{l}\text { Awareness of internal capability } \\
\text { gaps related to longer-term } \\
\text { improvements } \\
\text { Specialized organizational units } \\
\text { collect intelligence on local } \\
\text { and foreign markets and } \\
\text { technology } \\
\text { Difficulties in implementing am- } \\
\text { bitious learning strategies } \\
\text { effectively }\end{array}$ & $\begin{array}{l}\text { Increasing number of linkages to } \\
\text { foreign and knowledge-inten- } \\
\text { sive partners } \\
\text { Organizational arrangements } \\
\text { requiring high level of firm-in- } \\
\text { ternal effort } \\
\text { Asymmetric relationships princi- } \\
\text { pally aimed at building intern- } \\
\text { al capacity for innovation }\end{array}$ & $\begin{array}{l}\text { Purposive combination of a var- } \\
\text { iety of mechanisms for acquir- } \\
\text { ing external knowledge } \\
\text { Structured integration of external } \\
\text { knowledge through comple- } \\
\text { mentary internal learning } \\
\text { mechanisms and intra-organ- } \\
\text { izational knowledge } \\
\text { circulation }\end{array}$ \\
\hline Basic & $\begin{array}{l}\text { Focus on problems related to } \\
\text { basic routine testing and } \\
\text { maintenance } \\
\text { Poor interfaces with the external } \\
\text { environment for picking up } \\
\text { on opportunities for } \\
\text { improvement } \\
\text { Limited and unfocused strategies } \\
\text { for learning based on external } \\
\text { resources }\end{array}$ & $\begin{array}{l}\text { Reliance on local resources, with } \\
\text { limited linkages abroad } \\
\text { Learning through informal chan- } \\
\text { nels and/or production- } \\
\text { focused joint ventures } \\
\text { Unidirectional flow of knowledge } \\
\text { to build routine production } \\
\text { and investment capabilities }\end{array}$ & $\begin{array}{l}\text { Limited and ineffective use of } \\
\text { learning mechanisms based on } \\
\text { external sources of knowledge } \\
\text { Failure to follow up knowledge } \\
\text { acquisition with complemen- } \\
\text { tary internal efforts for know- } \\
\text { ledge integration }\end{array}$ \\
\hline
\end{tabular}

First, the latecomer firm needs to develop an awareness of its internal capability gaps (Arnold and Thuriaux, 1997; Rush et al., 2007). By gaps, we mean a distinct lack of specific sets of hardware, knowledge, skills, experience and organizational systems that prevent the firm from conducting its production- and investment-related operations at a high level of performance. Such gaps can stem from existing inadequacies with respect to the firm's ongoing operations, which is a key characteristic of the latecomer firm in the early stages of its development. Capability gaps can also emerge because of changes in the external environment, for example, in customers' needs, competitive pressures, or policies and regulations. Once identified, such gaps need to be articulated in the form of precisely defined technology and resource needs (Arnold and Thuriaux, 1997). These can act as focusing devices for the following steps in order to identify and make use of external sources of knowledge.

Since the latecomer firm is characterized by an initial lack of internal capabilities, it needs to develop the ability to identify resources that lie outside its organizational boundaries in order to address its internal shortages. This highlights a second important element of the firm's ability to envision linkages: its ability to scan and monitor its external environment (Arnold and Thuriaux, 1997). To do this effectively, the firm requires interfaces with the local environment, for example, with respect to relevant knowledge residing in local research institutions, developments in the demands of local clients, the availability of local production inputs, or changes in local policies or regulations. It also requires interfaces with the global environment, for instance, with respect to developments in global value chains or 
science and technology. The ability of the firm to pick up on signals in these areas is likely to depend on its investments in social networking, for example, maintaining close links to clients and suppliers, participating in industry associations, and attending industry fairs. It is also likely to depend on the amount of internal resources the firm allocates to this task, for instance, by creating specialized organizational units that collect intelligence on trends in markets and technology (e.g., see Amsden and Hikino, 1994).

Once relevant external resources have been identified, the firm needs to develop strategies to make effective use of them (Kiamehr et al., 2015; Kwak et al., 2018). We consider the ability to formulate such strategies to be a third component of the latecomer's ability to envision fruitful linkages. Such endeavors require the firm to align its overall competitive strategy with its learning objectives in light of the identified internal capability gaps (Scott-Kemmis and Chitravas, 2007). It also requires the alignment of learning strategies with specific learning mechanisms and activities that the firm wants to pursue (ibid.), an issue we return to when discussing to the exploitation category of capabilities below (Section 3.3). Developing effective strategies to make use of linkages to external resources requires a high level of intentionality. Indeed, while the passive absorption of knowledge through experience-based learning-by-doing typically results in limited learning, effective learning hinges on active, purposive, and concerted action (Bell and Pavitt, 1993). At the same time, learning processes take place over long periods of time, involve a high degree of uncertainty, and are often associated with the allocation of substantial human resources and financial expenditure. As such, it is critical that latecomer firms articulate strategies that seek to maximize learning outcomes while simultaneously mitigating these factors.

\subsubsection{Capability levels}

Next we discuss different levels of achievement with respect to the ability to envision linkages. In doing so, we discuss the three elements outlined above in an integrated manner for each capability level.

Latecomer firms that are at an early or "basic" stage of linkage capability-building tend to exhibit low awareness of their internal capability gaps. Typically they are unable to identify problems in their operations, aside from those relating to basic routine testing and maintenance activities (Arnold and Thuriaux, 1997). Furthermore, they tend to have underdeveloped interfaces to the outside world and, as such, are poorly equipped to pick up on signals about potential opportunities for improvements based on external resources. Focusing on small and medium-sized latecomer firms, Arnold and Thuriaux (1997: 10) argue that the limited scope of their search activities presents a key barrier in this respect:

(...) in many cases SMEs work within a small economic 'space'. This generally means working within a small geography, but it can also mean a tight linkage to a particular industrial sector or to the supply-chain of one or a small number of large companies. Lacking the resources to search widely for support and advice, SMEs tend in the first instance to work in interpersonal networks defined at these geographic and sectoral levels.

Given their preoccupation with short-term, operational problems, latecomer firms at the basic stage of developing their linkage capability usually pay limited attention to formulating strategies for long-term improvement. Generally, firms at this level are primarily concerned with engaging in linkages for the acquisition of equipment and operational know-how and do not focus on developing partnerships that could contribute to the building up of internal capabilities for changing existing or developing new technology (Dantas, 2006). In cases where firms do formulate strategies for longer-term improvements, these tend to lack focus and rigor and are often not followed up by appropriate measures for implementation (Scott-Kemmis and Chitravas, 2007).

Firms at the intermediate level of linkage capability development exhibit a higher level of awareness of opportunities for improvement from the external environment. They tend to establish some form of organizational unit that collects information on developments in markets and technologies, for example, by liaising with existing and potential future clients, monitoring competitor activity, keeping abreast of developments in science and technology, etc. (Kiamehr, 2012). Based on this, they develop strategies that are clearly focused on accessing external resources through linkages, for instance, to build up internal stocks of design knowledge required for creative problem-solving in production (Dantas, 2006). However, these firms still face a number of problems, for instance, with respect the speed at which they are able to respond to such opportunities (Scott-Kemmis and Chitravas, 2007). In other cases, firms face difficulties in translating the internal capability gaps they have identified into specific technological needs. For example, Kiamehr et al. (2015: 1247) discusses the case of an Iranian energy infrastructure developer: 
(...) in some cases Mapna was not able to identify the market needs well in advance, and even if it did, the firm had difficulties in translating them to technological needs, illustrating a lack of dialog and misalignment between marketing and R\&D. There were even cases in which the firm had identified a market need, had figured out a competitive proposition to respond to it, but the local engineers could not identify the advanced technologies needed. This was mostly a result of limited scope of technological networks of the firm, and the market and technology intelligence activities.

Firms at the advanced level of linkage capability-building have a high level of awareness of their internal capability gaps and of foresight in addressing such gaps. While Mathews (2002b: 472) does not include the ability of latecomer firms to envision opportunities for linkages in his "linkage-leverage-learning framework" (discussed in Section 2.1), he does highlight the role of the firm's awareness when he says:

It is in recognizing its deficiencies that the LCF [latecomer firm] secures its first competitive advantage. It formulates a strategy commensurate with its deficiencies and limitations. It harbors no illusions as to its own capabilities, and looks instead to the wider world for sources of technology, knowledge and market access.

Such advanced latecomers tend to make use of a multitude of external linkages, often to leading firms in industrialized economies. They use these linkages to benchmark their own performance, and thus to identify potential areas for improvement. This allows them to formulate effective strategies aimed at building up their stocks of capability for production- and investment-related activities. In the literature we reviewed, this idea is perhaps best captured in Scott-Kemmis's and Chitravas's (2007: 90/92) study of the Thai automotive industry, where they describe the most successful firms as follows:

(...) they actively sought information about their external environment, and they built relationships (often quite diverse relationships) with customers, suppliers and particularly international firms, to learn about the industry, policy, and technology. (...) These firms had an ability to nurture the long-term relationships with domestic and foreign partners (sometimes at a personal level) to enable them to 'keep the network alive'. They were able to leverage such relationship to quickly sense upcoming business opportunities, and in turn, learn to formulate ambitious strategies. These relationships also enabled the firms to gauge their own existing capabilities and learning needs and to assess 'what should I learn next'.

These firms' strategies tend to be focused, ambitious, and achievable (ibid.). Furthermore, latecomer firms at the highest level of capability development view their linkages to external partners not only as a means of sourcing knowledge for internal capability-building, but also as a strategic asset of complementary capabilities that the firm can draw on in its production and innovation activities (Dantas, 2006).

\subsection{Engaging in linkages}

\subsubsection{Key concepts}

Up to this point, we have discussed the firm's ability to envision fruitful linkages for learning in its production- or investment-related activities. Next, we discuss the capabilities that are required to engage with external resources in ways that are likely to result in learning. Here also, we distinguish three core elements.

First, the latecomer firm needs to decide what kinds of partners to build linkages to. ${ }^{1}$ These are commonly differentiated by type and origin. With respect to the former, there are many different kinds of relevant organization types, including suppliers of production inputs, clients, universities, research institutions, competitors, standard-setting bodies, and others. These have different resources-production inputs, user experience, design expertise, scientific knowledge, etc.- - to which the latecomer firm may require access. With regard to the origins of partners, a common differentiation is made on the basis of their geographical locations. External partners are often differentiated based on whether they are located within or outside the latecomer's host economy, where partners located in industrialized economies are usually associated with more advanced technological knowledge (Bell and Albu, 1999; Plechero, 2012; Hansen and Ockwell, 2014). The latecomer firm's ability to engage with external organizations of particular types and origins depends to a significant degree on its existing knowledge stock (Dantas and Bell, 2011; Figueiredo

1 This is determined by the latecomer's external interfaces and learning strategies and, as such, is closely related to the issues we discussed previously (Section 3.1). We elaborate on this aspect here (Section 3.2), as it is intertwined with other elements of engagement that we discuss below, including the nature of interorganizational arrangements that the latecomer establishes with external partners and the divisions of labour these entail. 
et al., 2013; Hansen and Lema, 2019). As in Section 3.1, this stock determines what the latecomer needs to learn next and, therefore, what kind of resources it needs to look out for.

Once the latecomer has identified an organization with the relevant resources, it needs to decide on an appropriate interorganizational form for the linkage. The nature of such organizational arrangements greatly affects the opportunities for capability-building that become available (Hobday, 1995; Fu and Zhang, 2011; Lema and Lema, 2012). There are many different types of arrangement involving different degrees of cooperation and integration, including arm's-length trade, joint ventures, licensing agreements, R\&D collaboration, and mergers and acquisitions. Interorganizational knowledge transfer can also take place through less formal channels, which are often referred to as knowledge spill-overs, such as sourcing knowledge from suppliers, labor mobility, or examining competitors' technology (Chen, 2009). While an exhaustive review of interorganizational forms is beyond the scope of our discussion, we emphasize that the latecomer firm is most likely to learn from external partners if it manages to arrange interorganizational forms that allow close interaction (Lema and Lema, 2012). As such, it should aim to engage in types of arrangements that not only allow the transfer of hardware and design specifications, but also access to non-codifiable or difficult-to-codify knowledge embodied in the personnel of the partner organization (Bell, 1990; Ockwell et al., 2010). This not only concerns knowledge about how to perform a certain process or how to operate and maintain a particular piece of equipment, but also how to adapt to and improve existing technology and to develop new technology.

An issue that is closely related to the choice of type of organizational arrangement is the division of labor that the latecomer establishes with its partner (Dantas and Bell, 2009). This involves defining the specific tasks involved in a collaboration and assigning roles and responsibilities to each partner in the execution of these tasks. While the nature of a particular type of organizational arrangement restricts the sorts of divisions of labor that are feasible, there can be substantial variation within a given arrangement type, as discussed, for example, by Nam (2011) for international joint ventures and Hansen et al. (2016) for foreign acquisitions. Rigorous knowledge exchange is most likely to take place in symmetric relationships, where firms share complementary resources on equal terms. This is likely to increase commitment and reduce opportunistic behavior (e.g., Nam, 2011). However, establishing such linkages can be challenging for the latecomer firm, especially during the early stages of its development, when it is primarily concerned with acquiring basic technical competences through one-way flows of knowledge from external partners into the firm.

\subsubsection{Capability levels}

As noted in Section 1, latecomer firms usually operate in isolation from advanced markets and sources of technology (Hobday, 1995) or lack the ability to access available networks (Bell and Figueiredo, 2012: 25). This highlights the importance of their capability to create linkages to foreign resources. Referring to firms in industrial clusters located in developing countries, Bell and Albu (1999: 1726) emphasize the need to make use of cluster-external, foreign sources of knowledge to progress past a certain stage:

This suggest that key features of the knowledge systems of clusters include not just their internal mechanisms for circulating the knowledge already available and for acquiring new knowledge from the experience of various kinds of 'doing'. Possibly more important is their openness to knowledge flows from outside. A scattering of empirical materials about these external flows suggests that relatively 'closed' knowledge systems may be associated with an inability to sustain competitiveness in the longer term.

Correspondingly, detailed empirical studies of latecomer capability-building that we reviewed find that firms which lack the ability to draw on foreign sources of knowledge usually do not develop product- or process-related capability stocks beyond those required for routine production activities (Plechero, 2012; Hansen and Ockwell, 2014). Latecomer firms that have basic linkage capabilities and that do engage with foreign partners often do so through international joint ventures that are principally aimed at generating local production capacity (Hansen and Lema, 2019). Such ventures typically do not contribute to the development of local innovation capability. This is especially the case in partnerships where there is a substantial gap in capabilities between the latecomer and its foreign partner, which can result in passive learning by the former (Nam, 2011). Regardless of the underlying type of organizational arrangement, firms at the basic level of linkage capability-building primarily experience one-way knowledge flows of resources, including hardware, codified knowledge, training, etc., aimed at developing a basic stock of production and investment-related capabilities in the firm. 
Firms at the intermediate stage of the linkage capability scale typically use linkages to external partners in order to build internal capabilities for innovation. For this purpose, they engage in more knowledge-intensive interactions with external partners, increasingly with advanced foreign partners. This also includes linkages to more knowledgeintensive kinds of organization, such as public research centers or specialized consultants (Dantas, 2006; Hansen and Lema, 2019). Furthermore, the predominant forms of organizational arrangements they engage in change compared to the basic level. For example, detailed studies of the Chinese solar photovoltaic (Quitzow et al., 2017) and East Asian electronics industries (Hobday, 1995) suggest that licenses from advanced foreign partners played a critical role once local firms have surpassed their initial stages of development. Such licensing requires more sophisticated prior capabilities and more internal effort by the latecomer firm, as knowledge is accessed in a less packaged form compared to a production-focused joint venture (Hobday, 1995: 1177). However, the division of labor in licensing agreements and other interorganizational forms at this stage are still marked by asymmetric relationships. The focus of the latecomer firm is still on sourcing knowledge in order to build up its internal capabilities, although this goes beyond the mere development of operational capabilities in production and investment to include efforts to develop the ability for engaging in innovation. In her detailed study of Petrobras, a Brazilian petroleum company, Dantas's (2006: 161) illustrates this point when she says:

Several forms of collaboration with various types of external sources of knowledge were used to obtain predominantly one-way knowledge flows from partners such as S\&T [science and technology] organisations, supply companies and other oil companies. Petrobras made efforts to increase its participation in knowledge production in its knowledge networks, but the division of tasks was still characterised mostly by asymmetric arrangements in which Petrobras learned from partners.

As discussed by Mathews (2002b), latecomer firms with advanced linkage capabilities are primarily focused on engaging in partnerships with leading foreign firms. Firms at this level of development might still invest in linkages with local organizations, including suppliers, clients, and local research institutes. However, they are characterized by a high frequency of engagement with advanced foreign firms, including a large variety of organizational types (Hansen and Lema, 2019). These partnerships are often based on forms of collaboration that involve high levels of investment and effort on the part of the latecomer, such as overseas R\&D programs and foreign acquisitions and mergers (e.g., Athreye et al., 2014). These have been referred to as “unconventional” technology transfer channels by Lema and Lema (2012) and are typically not only aimed at accessing advanced foreign knowledge but also function as vehicles for the co-design of technology (Dantas, 2006; Athreye et al., 2014). Some latecomer firms engage in substantial creative activity in these types of arrangement. For example, in our literature review, we identified a study by Lema et al. (2015: 1383) on partnerships between US American and Indian firms in the software industry, where the authors report the following:

In the course of dealing with advanced problem solving, some Indian software suppliers (...) acquire capabilities for problem framing (in technical fields) which some US lead firms are beginning to draw upon (...). Such independent suppliers as well as some MNC [multinational corporation] subsidiaries undertake highly creative work and activities are no longer just predefined by the buyer or the MNC headquarter.

Such outward-oriented, proactive organizational arrangements can enable advanced latecomer firms to engage in learning that is difficult to achieve based on inward-focused, "conventional" types of collaboration with external partners alone (Lema and Lema, 2012; Nam and Li, 2013).

\subsection{Exploiting linkages}

\subsubsection{Key concepts}

Once a form of engagement for a linkage has been decided, the latecomer firm needs to make use of the resources that become available through it. We conceptualize this as the exploitation stage of a linkage and distinguish two aspects.

First, the firm needs to acquire the specific kinds of resources it wants to access from its external partner. While earlier we discussed issues related to the origin and type of the external resource and the interorganizational form of partnership (Section 3.2), here we are concerned with the specific learning mechanisms that the latecomer employs to acquire access to the externally located knowledge. Several authors have compiled lists of relevant mechanisms (e.g., Kim, 1997; Figueiredo, 2003; Hansen and Ockwell, 2014). Bell and Figueiredo (2012) provide what is perhaps the 
clearest classification of learning mechanisms based on external resources, distinguishing between: various kinds of classroom-based and on-the-job training; the acquisition of codified knowledge, in the form of ready-made design specifications or as knowledge inputs to innovation processes (e.g., in the form of design software or patents); hiring human capital; and establishing a presence in technologically advanced regions, usually clusters in industrialized economies, to take advantage of knowledge spill-overs from leading firms. The organizational arrangement that the latecomer establishes with the external partner places limits on the types of learning mechanisms that are feasible in a particular context (Bell and Figueiredo, 2012; Lema and Lema, 2012). However, within these constraints the latecomer firm can still decide on which learning mechanisms to pursue and how many resources to devote to these efforts (e.g., see Yoruk, 2011). Detailed empirical case studies of latecomer learning suggest that intensity and variety in learning mechanisms are key determinants for the success of knowledge acquisition (Figueiredo, 2003).

In addition to acquiring external resources, the latecomer firm needs to integrate these into its prior stock of capabilities. Drawing on the literature on organizational learning (e.g., Nonaka, 1994), scholars of latecomer learning processes highlight the importance of the intraorganizational circulation of newly acquired knowledge (Kim, 1998; Figueiredo, 2003). This includes knowledge codification and socialization processes aimed at diffusing knowledge that was accessed by a limited number of firm personnel more widely within the organization. Additionally, external knowledge-acquisition processes often need to be complemented with investments in internal learning mechanisms (ibid.). This is especially important when knowledge is not accessed in a packaged form, for instance, when the latecomer firm acquires relevant pieces of knowledge from a variety of sources. This may require active efforts to combine different bits of knowledge with each other and with the firm's existing stock of capabilities, for example, through internal R\&D projects or trial-and-error experimentation in the firm's engineering department. Hence, to effectively exploit external resources, the latecomer firm needs to make parallel investments in knowledge acquisition and integration efforts, which often results in complex mixes of learning activities (Hansen and Ockwell, 2014; Hansen and Lema, 2019). As stressed earlier (Section 3.1), the use of such learning mechanisms needs to be closely aligned with the firm's overall learning strategy in order to contribute effectively to its more general competitive objectives (Scott-Kemmis and Chitravas, 2007).

\subsubsection{Capability levels}

At the basic level of linkage capability development, the latecomer firm exhibits a limited ability to acquire external resources and to integrate them into its internal capability stock. With regard to knowledge acquisition, detailed studies of less successful firms highlight the use they make of a limited variety of learning mechanisms. This often revolves around informal learning based on locally available knowledge, for example, during plant visits, in communications with industry experts, and when gathering feedback from local clients (e.g., Hansen and Ockwell, 2014). In cases where latecomers form partnerships with foreign organizations, they tend to underinvest in knowledge exploitation, either because of a lack of strategic intent or an inability to make use of the relatively advanced knowledge. This is illustrated in Figueiredo's (2000) detailed comparative case study of two Brazilian steel manufacturers, the less successful of which received a key opportunity to learn from a training course with an advanced foreign partner, but failed to do so due to the one-off nature of the course and limited organization-internal follow-up. With respect to knowledge integration, firms at the basic stage of linkage capability-building are characterized by similarly low levels of effort. For example, in Figueiredo's (2000) study, the less successful of the two firms did not create significant interactions between external and internal learning processes, resulting in limited intra-organizational knowledge diffusion. We also found that Tsekouras (2006: 143) presents a similar finding regarding a food-processing firm in Greece: ${ }^{2}$

DI was daring enough to sell a substantial part of its shares to FTNC [French Transnational Corporation] in return for just FTNC's expertise in yoghurt processing; unfortunately DI was not wise enough to make specific provisions in this agreement about the necessity to 'fuse' this incoming knowledge with in-house skills and knowledge. As a result, the lactic culture offered by FTNC could not be tailored to the specific needs of DI products, preventing the integration of relevant knowledge (...).

2 Tsekouras (2006) argues that, at the time of his study, Greece was an industrializing economy and that it is therefore appropriate to apply the concept of latecomer capability-building to this context. In other words, the firms that Tsekouras investigates in his study do not fall under the category of highly advanced firms that are typically the subject of studies in the literature on strategic management (Dutrénit, 2004). 
At the intermediate level of linkage capability-building, latecomer firms make use of mechanisms for knowledge acquisition in a more purposive and structured manner. For example, Hansen and Ockwell (2014) study the Malaysian biomass boiler industry and describe the case of a firm that managed to combine a variety of mechanisms to develop its internal production-related capabilities:

(...) the licence partnership with Volund [a Danish company] enabled employees from Alpha to access a highly skilled pool of expertise and learn about critical elements of advanced boiler designs, including vital calculation methods. This externally mediated learning by interacting process occurred during on-site plant visits, overseas training, and through technical assistance. This learning process was particularly intensive in the period after the second plant was constructed in 2004 when the management in Alpha was committed to persistently devoting efforts and resources to leverage learning through regular interaction and communication between employees in the respective firms.

Similarly, Figueiredo's (2000) comparative case study shows that the firm that engaged in more purposeful and variegated learning mechanisms was more successful in building its capabilities for production and investment. This included a variety of mechanisms for the intra-organizational circulation of knowledge in the form of internal seminars, in-house training programs, etc. Kim (1998) also offers a comprehensive investigation of intra-organizational mechanisms aimed at absorbing external knowledge in his study of Hyundai in South Korea. He explains that the company's knowledge-integration strategy involved multiple stages, including targeted preparation prior to knowledge acquisition, assimilation through learning-by-doing and using during and after knowledge acquisition, and incremental improvements based on lessons learnt.

Firms at the advanced level of linkage capability-building engage in strategic efforts for targeted knowledge acquisition. For example, Nam and Li (2013) discuss the case of the Shanghai Automotive Industry Corporation. While already operating at a relatively high level of competence, the firm realized the importance of augmenting its human resource pool. It therefore decided to invest in an R\&D-focused joint venture with a specialized consultancy firm based in the UK, which allowed it to access the expertise of the British firm's approximately 150 engineers. Learning mechanisms that take place as part of such outward-focused interorganizational partnerships, or "unconventional" technology-transfer channels, require substantial effort and resource investments from the latecomer firm (Lema and Lema, 2012). However, as briefly mentioned in Section 3.2, in some cases they appear to be a necessary complement to learning that can be facilitated through "conventional" types of organizational arrangement, as the latter might limit the sorts of learning mechanisms that the latecomer can make use of. When it comes to integrating knowledge, advanced firms are similarly strategic in using targeted learning efforts to internalize externally acquired knowledge. Discussing the cases of internationally competitive firms in the East Asian electronics industry, Mathews (2002b) encapsulates this idea when he says:

These [foreign] technologies are unlikely to be presented to the LCF in a discrete "chunk"; rather, they will have to be assembled from a variety of existing sources. This was certainly the case with the semiconductor industry, where chip fabrication equipment was progressively made available by commercial vendors through the 1980s, but Korean and Taiwanese firms had to be able to "mix and match" in order to build competitive production systems (...).

Similarly, Tsekouras (2006) goes into some detail about the knowledge integration efforts of firms in the Greek foodprocessing industry and highlights that the most successful firms were characterized by intensive efforts to leverage externally accessed knowledge for product and process development.

\section{Concluding discussion}

In this article, we have put forward a framework conceptualizing the development of linkage capabilities in latecomer firms. Our aim is to complement and add nuances to Lall's (1992) original framework on technological capabilities. As we explained in Section 1, Lall's framework distinguishes different capability functions the latecomer needs to develop in order to operate successfully in competitive markets. Most of these capability functions have been elaborated in further detail individually in the literature, usually with a focus on particular industries. For example, this includes studies going into significant detail about investment capabilities focused on project execution and pre- and post-project activities (e.g., Amsden and Hikino, 1994; Kiamehr, 2012) and production capabilities in product, process, and industrial engineering (e.g., Ariffin, 2000; Figueiredo, 2000; Hansen and Ockwell, 2014). In contrast, the existing literature on technological capability-building in latecomer firms has not addressed linkage capabilities or has simply 
adopted Lall's original conceptualization unchanged. For this reason, in this article, we have developed a conceptual framework that improves understanding of the relevant elements of a firm's ability to make effective use of external resources through linkages.

At this point, we note that, in addition to Lall $(1992)$, our work is inspired by Teece's $(2007,1997)$ framework for dynamic capabilities, which also differentiates three sub-capability types. This includes a firm's ability to sense opportunities and threats from changes in the environment, to seize opportunities, and to maintain its competitiveness by re-configuring and transforming its tangible and intangible assets. However, our framework differs from Teece's in important respects. First, Teece's $(2007,1997)$ framework deals with a sort of "meta-competence" for orchestrating various activities and sources of knowledge in order to create and recreate sources of competitive advantage (as also emphasized by Bell and Figueiredo, 2012: 57). Thus, dynamic capabilities constitute a rather broad range of capabilities within the firm. In contrast, our study focuses specifically on the development of linkage capabilities as a particular kind of capability that allows firms to make use of external sources of knowledge. Second, the elements we include in our framework differ from Teece's categorization. While our envisioning category largely overlaps with his notion of sensing opportunities and threats, when discussing the firm's capability to seize opportunities, we differentiate between engagement (setting up governance frameworks for interorganizational interactions) and exploitation (accessing and internalizing external knowledge that becomes available through linkages). Moreover, we do not consider the firm's ability to reconfigure and transform its existing resources in light of changes in the external environment. The reason for this choice relates to a third key difference between Teece's framework and ours, namely the fact we focus on latecomer firms while he, like strategic management scholars more generally, focuses on firms operating at the global frontier of innovation (Dutrénit, 2004; Bell and Figueiredo, 2012). As mentioned in Section 2, such firms are primarily concerned with nurturing and maintaining their already substantial capability stocks. In contrast, latecomer firms need to build up stocks of capabilities in the first place. As such, they are typically unable to respond to changes in the external environment by reconfiguring and transforming their existing assets.

To elaborate on this last point, we emphasize that it is important to consider the entire scale of latecomer capability development, including the early stages when the firm's capability stocks are characterized by distinct gaps in its stocks of knowledge, skills, experience, and organizational systems. Much of our understanding of latecomer capability-building processes is based on detailed studies of firms that have been highly successful and that today operate close to the global technological frontier (e.g., Hobday, 1995; Dutrénit, 1998; Kim, 1998; Figueiredo, 2000; Dantas, 2006). This includes our understanding of linkage capabilities, which to date has primarily been based on Mathews's (2002a, 2006, 2017) work on the so-called East Asian Dragon multinationals. While these are of course interesting firms to study, they also differ substantially from the vast majority of firms operating in the Global South, which have only accumulated a limited level of capabilities and which differ with respect to their size, access to capital and skilled labor, ties to government agencies, etc. Focusing research primarily on such high-performing firms can lead to bias in developing theory about latecomer capability-building processes. For this reason, we have developed our framework in a way that distinguishes between different levels of capability attainment, paying particular attention to how firms build their capability stocks from the ground up.

Furthermore, our framework explicitly distinguishes between the different types of capability that latecomer firms require to make effective use of external resources through linkages. Our decision to do this stems from a gap we observed in the current literature on latecomer capability-building processes. While linkages to external actors are considered a key element of technological learning processes, only limited theoretical development has taken place regarding the kinds of capabilities firms require in order to develop effective linkages (apart from the previously mentioned work by Mathews in the international business literature). Accordingly, studies of latecomer capability-building treat linkages with external parties mostly as a source of learning, rather than as a distinct category of capabilities that latecomer firms can develop and nurture. Most of this literature seems to analyze linkages in an ad hoc manner, their importance being acknowledged, but how they were developed in the first place rarely being addressed systematically. Specifically, when focusing on particular types of capabilities that are relevant for linkages, the vast majority of these studies appear to focus on how firms exploit existing linkages in order to integrate external sources of knowledge with their internal knowledge stocks (for a review, see Bell and Figueiredo, 2012). While our review of the literature has identified some scattered insights on other aspects of linkages (see Section 3.1. on "envisioning" and Section 3.2 on "engagement"), this concerns a comparatively small number of studies. Thus, the existing literature provides few insights into the kinds of capabilities that the latecomer firm requires in order to be able to identify 
relevant linkages and to choose suitable organizational arrangements (Nam [2011] is an exception). Given the current lack of a well-developed theoretical understanding that can answer questions about these issues, our framework contributes to advancing the existing literature by considering the different types of capability that firms use to envision, engage in, and exploit linkages.

While conceptually distinguishable, the three elements of linkage capabilities that we describe in our framework are likely to exhibit some interdependencies. For example, we expect a firm's ability to envision fruitful linkages to affect the kinds of interorganizational partnership forms that it is able to establish with other organizations. Indeed, a firm that develops an ambitious and realistic learning strategy is likely to try and engage with partners in ways that involve a high degree of interactive learning, and will thus invest resources in the establishment of suitable interorganizational arrangements. We similarly expect the form of interorganizational partnership to affect the firm's ability to exploit the external resources that become available through it. As we discuss above, the organizational arrangement defines the tasks and responsibilities of each partner in a linkage and can therefore limit the types of learning mechanism that the latecomer can make use of (Bell and Figueiredo, 2012; Lema and Lema, 2012). Finally, experience in exploiting external sources of knowledge is likely to impact on the firm's ability to identify new partners and to choose appropriate forms of engagement in the future. In fact, firms which are most successful in leveraging linkages for technological learning tend to use their knowledge acquisition and integration efforts as an impetus to identify further gaps in their capability stocks and to determine what to learn next (Scott-Kemmis and Chitravas, 2007). Thus, in general, we expect the latecomer firm to develop its capabilities to envision, engage in, and exploit linkages more or less simultaneously. However, in practice, firms might develop these capability elements unevenly, potentially due to imbalances in efforts and investments across these linkage capability elements. This might then limit their ability to take full advantage of the available sources of external knowledge. Our framework provides a conceptual starting point for thinking about these issues.

We conclude our article by briefly highlighting some issues that our framework raises but does not discuss in detail. First are the features of the learning mechanisms through which the latecomer firm builds its linkage capabilities. As depicted in the top half of Figure 1 (Section 3), there are sets of learning mechanisms that firms can make use of to build their capability stocks. In the case of production and investment capabilities, this includes a variety of internal and external learning mechanisms (e.g., see Kim, 1997; Figueiredo, 2003; Hansen and Ockwell, 2014). We have argued that linkages to external partners are key to learning aimed at developing production and investment capabilities. In addition, one can also think of specific learning mechanisms aimed at building linkage capabilities. Mathews and Cho (1999: 153) refer to this as "learning how to learn." Such learning can involve different degrees of effort and investment by the latecomer firm. It can be relatively passive, for example, involving the mere accumulation of experience by individual staff members who go through repeated cycles of envisioning, engaging in, and/or exploiting external resources. Learning can also be more active, for instance, by means of investing in circulating knowledge of best practices and past experiences within the organization (Nonaka, 1994). This includes co-ordinated knowledge exchange within the firm, for example, between staff in charge of business development and the collection of technology and market intelligence on the one hand, and those dealing with the incorporation of externally accessed knowledge in the firm's R\&D and engineering departments on the other (e.g., Kiamehr et al., 2015). As with any other type of capability, learning in linkage-building is likely to be most effective if it involves active, purposive, and concerted action (Bell and Pavitt, 1993).

Our article also raises some issues regarding the relationship between linkage capabilities and other types of capability functions, specifically those related to production and investment activities. Lall (1992:168) argues that there is no particular sequence in which a firm needs to develop different capability functions. Instead, the firm requires basic competences in each function in order to operate in competitive markets. This contrasts with alternative conceptualizations of latecomer capability development, which postulate that firms usually goes through a sequence of capability-building, first for production purposes, then for investment, and finally for innovation (Dahlman et al., 1987; Kim, 1997; Amsden, 2001). While we agree with Lall that the firm needs to build different capability categories in parallel, we emphasize here that there are important interaction effects between different capability functions. These interactions are likely to influence the latecomer firm's overall progression of technological capability development. As we argued earlier, the accumulation of linkage capabilities allows the firm to make use of external resources in order to build other types of capability, including those required for production and investment activities. To progress past a basic stage of capability development, the firm usually needs to make use of external resources both in the local economy and abroad (Hansen and Lema, 2019). At the same time, the firm's capabilities in terms of 
production and investment are likely to affect the various elements of its linkage capabilities, including its ability to identify further useful linkages, to set up suitable forms of interaction with external resources, and to exploit these resources. This two-way relationship has been studied in the case of production capabilities and learning mechanisms, where the latter are mainly conceptualized as mechanisms for knowledge exploitation (Figueiredo et al., 2013; Hansen and Lema, 2019). Our framework provides a conceptual starting point to think about interactions between linkage capabilities, defined more comprehensively than in the previous literature, and other kinds of capabilities.

Finally, we highlight the need to consider how differences across industries affect the nature of the most relevant kinds of linkages between firms and external partners. By extension, one should also consider differences in the kinds of linkage capabilities a latecomer firm needs to develop in order to learn effectively from external sources. For instance, in mass-manufacturing industries, competitiveness mainly stems from economies of scale and efficiency improvements in production processes and supply chains (Abernathy and Utterback, 1988). Microlevel studies of technological catch-up in such industries have emphasized specific kinds of linkages, including those with foreign providers of turnkey production lines and relevant training services, material input suppliers, local or foreign buyers, and linkages related to logistics (e.g., Hobday, 1995; Quitzow et al., 2017). On the other hand, project-based industries involve complex product systems that require substantial adaptations to the specific circumstances of each project (Miller et al., 1995; Hobday, 1998). Here, key capability categories include design, system integration, and project-planning and execution, which are typically acquired through direct involvement in projects (Prencipe, 1997; Davies and Brady, 2000). Microlevel studies focusing on latecomer capability-building in these types of industry emphasize different sets of linkages, including those to users in order to determine project needs and those to suppliers of appropriate system components (e.g., Kiamehr, 2017). These differences across industries affect all three dimensions of our linkage capability framework, including the choice of the most suitable partners (and where to look for them), the kinds of partnership agreements to choose that are most likely to provide access to the required knowledge, and the specific kinds of activities needed to make effective use of the knowledge that becomes available through particular linkages.

\section{Appendix}

The online version of this article includes a table with quotes from the literature on microlevel latecomer capabilitybuilding processes that serve to illustrate the different elements which we discuss in our analytical framework.

\section{Acknowledgments}

The authors would like to thank the editor and three anonymous reviewers for their comprehensive and insightful feedback on this work.

\section{Funding}

This project received funding from the European Union's Horizon 2020 Research and Innovation Programme under Marie Skłodowska-Curie grant agreement No. 713683.

\section{References}

Abernathy, W. J. and J. M. Utterback (1988), 'Innovation over time and in historical context,' in M.L. Tushman and B. Moore (eds), Readings in the Management of Innovation. Harper Collins Publishers, New York, pp. 25-36.

Amsden, A. H. (2001), The Rise of "the Rest": Challenges to the West from Late-Industrializing Economies. Oxford University Press, Oxford.

Amsden, A. H. and T. Hikino (1994), 'Project execution capability, organizational know-how and conglomerate corporate growth in late industrialization,' Industrial and Corporate Change, 3(1), 111-147.

Ariffin, N. (2010), 'Internationalisation of technological innovative capabilities: levels, types and speed (learning rates) in the electronics industry in Malaysia,' Technological Learning, Innovation, and Development, 3(4), 347-391.

Ariffin, N. (2000), 'The internationalisation of innovative capabilities: the Malaysian electronics industry,' doctoral thesis. University of Sussex, UK. 
Ariffin, N. and P. N. Figueiredo (2004), 'Internationalization of innovative capabilities: counter-evidence from the electronics industry in Malaysia and Brazil,' Oxford Development Studies, 32(4), 559-583.

Arnold, E. and B. Thuriaux (1997), 'Developing firms' technological capabilities.' Technopolis. Technopolis Report 43.

Athreye, S., A. Tuncay-Celikel and V. Ujjual (2014), 'Internationalisation of R\&D into emerging markets: fiat's R\&D in Brazil, Turkey, and India,' Long Range Planning, 47(1-2), 100-114.

Barney, J. (1991), 'Firm resources and sustained competitive advantage,' Journal of Management, 17(1), 99-120.

Bell, M. (1990), 'Continuing industrialisation, climate change, and international technology transfer.' University of Sussex, Brighton.

Bell, M. and M. Albu (1999), 'Knowledge systems and technological dynamism in industrial clusters in developing countries,' World Development, 27(9), 1715-1734.

Bell, M. and P. N. Figueiredo (2012), 'Building innovative capabilities in latecomer emerging market firms: some key issues,' 24-110, in E. Amann, J. Cantwell (eds), Innovative Firms in Emerging Market Countries. Oxford University Press, Oxford.

Bell, M. and K. Pavitt (1993), 'Technological accumulation and industrial growth: contrasts between developed and developing countries,' Industrial and Corporate Change, 2(2), 157-210.

Bell, M. and K. Pavitt (1995), 'The development of technological capabilities,' in Trade, Technology, and International Competitiveness. World Bank, Washington, DC, pp. 69-101.

Caniels, M. C. J. and H. Romijn (2004), 'Technological learning in small-enterprise clusters: conceptual framework and policy implications,' in S. Mani and H. Romijn (eds), Innovation, Learning, and Technological Dynamism in Developing Countries. United Nations University Press, Paris, pp. 135-157.

Chen, L.-C. (2009), 'Learning through informal local and global linkages: the case of Taiwan's machine tool industry,' Research Policy, 38(3), 527-535.

Dahlman, C. J., B. Ross-Larson and L. E. Westphal (1987), 'Managing technological development: lessons from the newly industrializing countries,' World Development, 15(6), 759-775.

Dantas, E. (2006), 'The development of knowledge networks in latecomer innovation systems: the case of Petrobras in the Brazilian offshore oil industry,' doctoral thesis. University of Sussex, Brighton.

Dantas, E. and M. Bell (2009), 'Latecomer firms and the emergence and development of knowledge networks: the case of Petrobras in Brazil,' Research Policy, 38(5), 829-844.

Dantas, E. and M. Bell (2011), 'The co-evolution of firm-centred knowledge networks and capabilities in late industrializing countries: the case of Petrobras in the offshore oil innovation system in Brazil,' World Development, 39(9), 1570-1591.

Davies, A. and T. Brady (2000), 'Organisational capabilities and learning in complex product systems: towards repeatable solutions,' Research Policy, 29(7-8), 931-953.

Dutrénit, G. (1998), 'From knowledge accumulation to strategic capabilities: knowledge management in a Mexican glass firm,' doctoral thesis. University of Sussex, UK.

Dutrénit, G. (2004), 'Building technological capabilities in latecomer firms: a review essay,' Science, Technology, and Society, 9(2), 209-241.

Dutrénit, G., K. Lee, Lee, R. Nelson, L. Soete and A. O. Vera-Cruz (2013), Learning, Capability Building, and Innovation for Development. Palgrave Macmillan, New York.

Eisenhardt, K. M. and J. A. Martin (2000), 'Dynamic capabilities: what are they?,' Strategic Management Journal, 21(10-11), 1105-1121.

Figueiredo, P. N. (2000), 'Technological capability-accumulation paths and the underlying learning processes in latecomer context: a comparative analysis of two large steel companies in Brazil,' doctoral thesis. University of Sussex, UK.

Figueiredo, P. N. (2003), 'Learning, capability accumulation and firms' differences: evidence from latecomer steel,' Industrial and Corporate Change, 12(3), 607-643.

Figueiredo, P. N. (2017), 'Micro-level technological capability accumulation in developing economies: insights from the Brazilian sugarcane ethanol industry,' Journal of Cleaner Production, 167, 416-431.

Figueiredo, P. N., M. Cohen and S. Gomes (2013), 'Firms' innovation capability-building paths and the nature of changes in learning mechanisms: multiple case-study evidence from an emerging economy,' UNU Merit Working Paper, 2013-2007.

Forkmann, S., S. C. Henneberg and M. Mitrega (2018), 'Capabilities in business relationships and networks: research recommendations and directions,' Industrial Marketing Management, 74, 4-26.

$\mathrm{Fu}, \mathrm{X}$. and J. Zhang (2011), 'Technology transfer, indigenous innovation and leapfrogging in green technology: the solar-PV industry in China and India,' Journal of Chinese Economic and Business Studies, 9(4), 329-347.

Gammeltoft, P. (2004), 'Development of firm-level technological capabilities,' Journal of Asia Pacific Economy, 9(1), 49-69.

Hansen, U. E., N. Fold and T. Hansen (2016), 'Upgrading to lead firm position via international acquisition: learning from the global biomass power plant industry,' Journal of Economic Geography, 16(1), 131-153.

Hansen, U. E. and R. Lema (2019), 'The co-evolution of learning mechanisms and technological capabilities: lessons from energy technologies in emerging economies,' Technological Forecasting and Social Change, 140, 241-257. 
Hansen, U. E. and D. Ockwell (2014), 'Learning and technological capability building in emerging economies: the case of the biomass power equipment industry in Malaysia,' Technovation, 34(10), 617-630.

Hobday, M. (1995), 'East Asian latecomer firms learning the technology of electronics,' World Development, 23(7), 1171-1193.

Hobday, M. (1998), 'Product complexity, innovation, and industrial organisation,' Research Policy, 26(6), 689-710.

Iammarino, S., R. Padilla-Pérez and N. von Tunzelmann (2008), 'Technological capabilities and global-local interactions: the electronics industry in two Mexican regions,' World Development, 36(10), 1980-2003.

Kiamehr, M. (2012), 'The evolution of systems-integration capability in latecomer contexts: the case of Iran's thermal and hydro power generation systems,' doctoral thesis. University of Brighton, UK.

Kiamehr, M. (2017), 'Paths of technological capability building in complex capital goods: the case of hydro electricity generation systems in Iran,' Technological Forecasting and Social Change, 122, 215-230.

Kiamehr, M., M. Hobday and M. Hamedi (2015), 'Latecomer firm strategies in complex product systems (CoPS): the case of Iran's thermal electricity generation systems,' Research Policy, 44(6), 1240-1251.

Kim, L. (1997), Imitation to Innovation: The Dynamics of Korea's Technological Learning. Harvard Business School Press, Boston.

Kim, L. (1998), 'Crisis construction and organizational learning: capability building in catching-up at Hyundai Motor,' Organization Science, 9(4), 506-521.

Kwak, K., W. Kim and K. Kim (2018), 'Latecomer firms' combination of strategies in a specialized suppliers sector: a comparative case study of the Korean plastic injection molding machine industry,' Technological Forecasting and Social Change, 133, $190-205$.

Lall, S. (1992), 'Technological capabilities and industrialization,' World Development, 20(2), 165-186.

Lambe, C. J., R. E. Spekman and S. D. Hunt (2002), 'Alliance competence, resources, and alliance success: conceptualization, measurement, and initial test,' Journal of the Academy of Marketing Science, 30(2), 141-158.

Lema, R. and A. Lema (2012), 'Technology transfer? The rise of China and India in green technology sectors,' Innovation and Development, 2(1), 23-44.

Lema, R., R. Quadros and H. Schmitz (2015), 'Reorganising global value chains and building innovation capabilities in Brazil and India,' Research Policy, 44(7), 1376-1386.

Lorenzoni, G. and A. Lipparini (1999), 'The leveraging of inter-firm relationships as a distinctive organisational capability: a longitudinal study,' Strategic Management Journal, 20(4), 317-338.

Mathews, J. A. (2002a), Dragon Multinational: A New Model of Global Growth. Oxford University Press, New York.

Mathews, J. A. (2002b), 'Competitive advantages of the latecomer firm: a resource-based account of industrial catch-up strategies,' Asia Pacific Journal of Management, 19(4), 467-488.

Mathews, J. A. (2006), 'Dragon multinationals: new players in 21st century globalization,' Asia Pacific Journal of Management, 23(1), 5-27.

Mathews, J. A. (2017), 'Dragon multinationals powered by linkage, leverage and learning: a review and development,' Asia Pacific Journal of Management, 34(4), 769-775.

Mathews, J. A. and D. Cho (1999), 'Combinative capabilities and organizational learning in latecomer firms: the case of the Korean semiconductor industry,' Journal of World Business, 34(2), 139-156.

Miller, R., M. Hobday, T. Leroux-Demers and X. Olleros (1995), 'Innovation in complex systems industries: the case of flight simulation,' Industrial and Corporate Change, 4(2), 363-400.

Mitrega, M., S. Forkmann, C. Ramos and S. C. Henneberg (2012), 'Networking capability in business relationships: concept and scale development,' Industrial Marketing Management, 41(5), 739-751.

Nam, K.-M. (2011), 'Learning through the international joint venture: lessons from the experience of China's automotive sector,' Industrial and Corporate Change, 20(3), 855-907.

Nam, K.-M. and X. Li (2013), 'Out of passivity: potential role of OFDI in IFDI-based learning trajectory,' Industrial and Corporate Change, 22(3), 711-743.

Nonaka, I. (1994), 'A dynamic theory of organizational knowledge creation,' Organization Science, 5(1), 14-37.

Ockwell, D. G., R. Haum, A. Mallett and J. Watson (2010), 'Intellectual property rights and low carbon technology transfer: conflicting discourses of diffusion and development,' Global Environmental Change, 20(4), 729-738.

Penrose, E. T. (1959), The Theory of Growth of the Firm. Wiley, New York.

Plechero, M. (2012), 'The changing geography of innovation: Chinese and Indian regions and the global flows of innovation,' doctoral thesis. Lund University, Sweden.

Prencipe, A. (1997), 'Technological competencies and product's evolutionary dynamics: a case study from the aero-engine industry,' Research Policy, 25(8), 1261-1276.

Quitzow, R., J. Huenteler and H. Asmussen (2017), 'Development trajectories in China's wind and solar energy industries: how technology-related differences shape the dynamics of industry localisation and catching-up,' Journal of Cleaner Production, 158, 122-133.

Romijn, H. (1997), 'Acquisition of technological capability in development: a quantitative case study of Pakistan's capital goods sector,' World Development, 25(3), 359-377. 
Rush, H., J. Bessant and M. Hobday (2007), 'Assessing the technological capabilities of firms: developing a policy tool,' R\&D Management, 37(3), 221-236.

Scott-Kemmis, D. and C. Chitravas (2007), 'Revisiting the learning and capability concepts: building learning systems in Thai auto component firms,' Asian Journal of Technology Innovation, 15(2), 67-100.

Teece, D. J. (2007), 'Explicating dynamic capabilities: the nature and micro-foundations of (sustainable) enterprise performance,' Strategic Management Journal, 28(13), 1319-1350.

Teece, D. J., G. Pisano and A. Shuen (1997), 'Dynamic capabilities and strategic management,' Strategic Management Journal, 18(7), 509-533.

Tsekouras, G. (2006), 'Gaining competitive advantage through knowledge integration in a European industrialising economy,' International Journal of Technology Management, 36(1/2/3), 126.

Whitfield, L., C. Staritz, A. T. Melese and S. Azizi (2020), 'Technological capabilities, upgrading, and value capture in global value chains: local apparel and floriculture firms in Sub-Saharan,' Africa. Economic Geography, 96(3), 195-124.

Yoruk, E. (2011), 'The influence of technological capabilities on the knowledge network component of innovation systems: evidence from advanced materials in Turkey,' International Journal of Technological Learning, Innovation and Development, 4(4), $330-362$. 